\section{スボーツによる性格治塨の研究（その 1)}

一少年院におけるスポーツの指道法に関する研究一

東京教青大学 $\bigcirc$ 松田 岩男, 鈴木 清

田中 英彥，近藤 充夫

市村 操一

順天堂大学 太田 哲男, 松永 春代

\section{研究の目的}

本研究は，スポーツによる性格治療の方法を笑験的に 研究するために，非行少年少女およびその前段倩にみら れる情楮不安定児など，性格上の問題児を対象として， 調査やスポーッの指導を試み，それを通して研究を進め ているものである.

スポーツが性格治療に効果があることは，Davisなど も注目し, Recreational Therapy として,スポーツを あげている．また，わが国でも「体育実験少年院」とし て各種のスポーツの指導を試みているところがある.

性格治療はむうかかい問題であるが，一般に性格がよ くなるとは，(1)価值観の変化，(2)自己統制（Self cont$\mathrm{rol}$ ) の強化，(3対人関係の 改善（個人的態度 $\rightarrow$ 協力的 態度）がなされることを意味する。

スポーツは，その身体的・心理的特性から，自己防衛 機制を低下させる働きをるち，指導者と対象との間に親 和感をるつことを容易にすると考えられる。

また，自主的な楽しい活動として，楽しみながら自己 統制をさせることが可能であり，この親和的，相互協力 的場面において, 価値観の変化, 対人関係の改善をもた らすことが可能であると考えられる。

以上の仮説に基づいて，少年院ならびに中・高校に拉 ける問題児を対象としてスポーッの指導を試み，その過 程の分析，態度の変化などを把えて指導法を政善しつつ 効果的な指導法の確立を目指している。

\section{研究の方法}

昨年の 7 月から具体的な研究に着手し，少年院ととも に中・高校の問題児にもスポーツの指導を試みたが，本 年度は少年院の研究のみを報告する。

バレーボール，ソフトボール，バスケツトボールなど とともに, 少女にはフオークダンスなどの指尊む試みた が，少年院に猢りスポーツの指導は，一般の中・高校 とは異り，拘禁状態に打ける指導であるといら特色があ
る.すなわち，少年院に収容されて一定の作業が計画的 に課されて和り，スボーツの指導をしているときです， 少年院の指導者数名が周囲から監視しており，その中で スポーツが行なわれる．また，従来，少年院におけるス ポーッの指導についてみると，少年少女が自主的に運動 するといらよりす，むしろ，強制的であり，規律訓練的 効果がより多く期待されており，いま1つの自由な自主 的な特性が十分に活用されていないようである.

これらの観点を考えて，規律訓練的効果と自主的自由 な活動としての効果の両面を調和させる立場をとり，小 グループによる指導を試みた。

なお，性格や態度の变化をとらえるために，YG 性格 検査，精神健康検查，社会的適応性検查をはじめ，スポ 一ツに対する興味の調查および行動観察などを実施して いるが, 行動観察については, スポーツの場面に批る 態度・行動に問題児の特徵が見られるので，非行児・問 題児を通して子测するための行動観察の規準の作成を試 みている。これは予測たりでなく，そこにみられる特徵 をとらえて指導することを試みるつるりである。

\section{本研究の問通点}

研究はその途上にあり，その結果の一部は（その 2) （その3）で報告するが, 本研究の問題点として次の点 があげられる。

(1) 現在までのところ, 若干の効果が認められるが, 少年院に収容されている少年少女は，身体運動が不足す る傾向があり，スポーツに上る身体運動の結果か、スポ ーツによるグループ活動の結果かが不明である.

(2) 少年院の少年少女に対するスポーツの指導は, 少 年院の指導者の監視下においてなされるるのであり，そ の範囲を脱することができない，監視下に执いて，どれ だけの自主性や自由を認めるか, 他律から自律への転換 をいかにするかなどの閶題がある.

(3)このよらな状況下でスポーツの場面で適応がよく なるとすればどうすれば，スポーツに憘んで参加する か, 彼等に対するスポーツの指導において, 勝敗が含ま れた方がいかどらかなどを究明することが必要であ り，それらに基づいて，具体的なスポーツの処方をくふ らしなければならない。

本年度は以上の上うな問題の究明に努めている。 